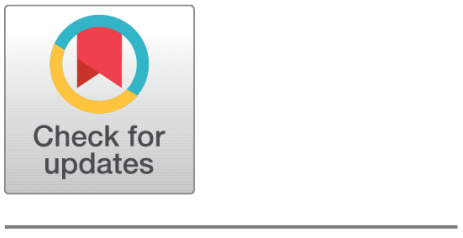

OPEN ACCESS

Received: 05-04-2020

Accepted: 23-04-2020

Published: 18-06-2020

Editor: Dr. Natarajan Gajendran

Citation: Idowu EO, Alebiosu C (2020) Ichthyofauna composition of Alape River, Igbokoda, South West Nigeria. Indian Journal of Science and Technology 13(19): 1882-1889. https://doi.org/ 10.17485/IJST/v13i19.136

*Corresponding author. Eunice Opeyemi Idowu

Department of Zoology and Environmental Biology, Faculty of Science, Ekiti State University, Ado Ekiti, Ekiti State, Nigeria.

Tel.: 08039422005

eunice.idowu@eksu.edu

Funding: None

Competing Interests: None

Copyright: (c) 2020 Idowu, Alebiosu. This is an open access article distributed under the terms of the Creative Commons Attribution License, which permits unrestricted use, distribution, and reproduction in any medium, provided the original author and source are credited.

Published By Indian Society for Education and Environment (iSee)

\section{Ichthyofauna composition of Alape River, Igbokoda, South West Nigeria}

\author{
Eunice Opeyemi Idowu ${ }^{1 *}$, Charlse Alebiosu ${ }^{1}$ \\ 1 Department of Zoology and Environmental Biology, Faculty of Science, Ekiti State \\ University, Ado Ekiti, Ekiti State, Nigeria. Tel.: 08039422005
}

\section{Abstract}

Objectives: To study ichthyofauna composition of Alape River, Igbokoda, Ilaje Local Government Area of Ondo State, Nigeria. Method: Sampling was done for a period of three months, from the month of November 2019 to January 2020. Data for this study were based on the record of fish caught by local fishermen. Findings: A total of twenty thousand, four hundred and nine $(20,409)$ individual fishes of six species (Heterotis niloticus, Clarias gariepinus, Chrysichthys nigrodigitatus, Gymnarchus niloticus, Oreochromis aureaus and Hepsetus odoe), belonging to six families (Arapaimidae, Clariidae, Claroteidae, Gymnarchidae, Cichlidae and Hepsetidae) were recorded for the whole period of study. The over-all comparison among the months of study shows that January recorded the highest catch $(6,919)$ with an over-all relative percentage abundance of $33.9 \%$, followed by December $(6,871)$ with $33.67 \%$. The least catch $(6,619)$ was observed in the month of November with a relative percentage abundance of $32.43 \%$. The study showed that Clarias gariepinus and Oreochromis aureus were dominant fish species, Chrysichthys nigrodigitatus was sub-dominant, Heterotis niloticus and Hepsetus odoe were occasional while Gymnarchus niloticus was rare in River Alape. The results of this study showed that the river has low fish species composition and abundance in spite of the size of the river. Considering this fact, there is need for further survey to cover more months. There is also a need to evolve strategies for effective utilization and proper management of the river for optimum fish production, sustainability and conservation.

Keywords: Ichthyofauna; Abundance; Composition; Alape River

\section{Introduction:}

In a developing country such as Nigeria, fish serves as a major source of food contributing up to a total of $40 \%$ dietary protein requirements and a readily available source of animal protein in the diet of man owing to myriads of cognate facts a few of which is that fish is highly nutritious with balanced amino-acids, minerals and vitamins for healthy human growth, it is less tough and more digestible when compared with chicken, beef and mutton. A more cognate reason is because fish is highly palatable, contains low cholesterol, has a tender flesh, has a good aroma in cooking and of course for the most economical reasons, it is cheap. As a matter of fact, fish is known to be one of the 
cheapest sources of animal protein having essential nutrients needed in human diets ${ }^{(1)}$.

Nigeria is blessed with over 14 million hectares of reservoirs, lake, ponds and major rivers capable of producing over 980,000 metric tons of fish annually ${ }^{(2)}$. With a coastline of $853 \mathrm{~km}, 200$ nautical miles Exclusive Economic Zone (EEZ), over 2,658 fish farms as well as 937 dams and reservoirs, 365 lakes and reservoirs and 687 ponds and floodplains covering over 13 million ha of water bodies have immensely contributed economically, socially and culturally to the development of the country through hydroelectric power generation, irrigation, recreation, research and has an enviable potential for fish production ${ }^{(3)}$. This shows beyond doubt why Nigeria is a fishing country and Nigerians are fish eating people. Thus, is need to protect and manage the fishery resources for the community.

The fish fauna of the Nigerian freshwater system has been the focus of research for quite some time, investigations into the biodiversity of fish species of Nigerian inland water bodies have been carried out by various scientists. These include the works of ${ }^{(4-9)}$. These studies concentrated more on lakes and wet lands, the few available researches on rivers are concentrated on larger water bodies such as River Niger, Lake Chad etc. with less attention on small rivers. The lesser known water bodies are neglected, yet they contribute significantly to local fish supply. The global level of fish supply is becoming insufficient as a result of human pressure due to population increases ${ }^{(10)}$. Nigeria population which was estimated at about 165 million in 2011 with an annual population growth rate of $2.1 \%$ is expected to be 270 million by the year 2030 . Hence food supply including fish is expected to triple to cater for this increase ${ }^{(11)}$.

The current fish demand in Nigeria is about 3.21 million tons and the current total production is about 1.2 million tons ${ }^{(2)}$. The artisanal fishery sector constitutes the most important sector of fisheries as it accounts for the major fish supply in the developing world. Over $90 \%$ of domestic fish production in Nigeria comes from this sector ${ }^{(12)}$. These, if properly managed and sustained can subsidize the high protein demand of the ever- increasing population and also boost their economy. Moreover, Ilaje is fast-growing and developing into a big city. These bring along human anthropogenic activities and unrestricted dumping of pollutants into the river. Thus, there is a dire need to have a comprehensive update and baseline documentation of the piscine assemblage of this important river. This study will however provide a comprehensive baseline data on the ichthyofauna assemblage of Alape River, Igbokoda in Ilaje Local Government Area of Ondo State, Nigeria. This therefore justifies the intent of the study. The aim of the study therefore, is to survey the icthytofauna composition of Alape River Igbokoda, Ilaje Local Government Area of Ondo State, Nigeria. The objectives of the study are: to ascertain the abundance, composition, distribution of fish species and to provide a comprehensive baseline data on the fish species in Alape River.

\section{Materials and Methods}

\subsection{Study Area}

The study was carried out in Alape River, Igbokoda in Ilaje Local Government Area of Ondo State, Nigeria. The upstream of Igbokoda River is known to be the Alape River which is one of the major and important rivers in Ondo State, Nigeria. The river lies on latitude $4^{\circ} 40^{\prime}-5^{\circ} 00^{\prime} \mathrm{N}$ and $6^{\circ} 00^{\prime}-6^{\circ} 20^{\prime} \mathrm{E}$. Alape River is a natural habitat of freshwater fishes. The river serves as means of transportation to other states like Lagos, Ogun and Delta States among others.

\subsection{Sampling of fish species}

Sampling was done for a period of three months, from the month of November 2019 to January 2020. Data for this study were based on the record of fish caught by local fishermen. The collection of samples was done once in a week from the landing site of the fishermen. The fishermen used different mesh sizes of set nets $(5 \mathrm{~mm}-22 \mathrm{~mm})$ and hooks. The setting of these gears were mostly done in the evenings by $6.00 \mathrm{pm}$ and left overnight, till $6.30 \mathrm{a} . \mathrm{m}$. The catches were collected, sorted into species and families on the field, collected into ice coolers and transported to the laboratory, where they were preserved inside a deep freezer prior to further examination.

\subsection{Fish identification}

Most of the species caught by these fishermen at the river were sorted into various families and counted. The identification was done both on the field by fishermen and in the Zoology Laboratory using identification guides ${ }^{(13,14)}$.

\subsection{Data analysis}

All fish species collected were counted to determine species abundance. The relative abundance (\%) of each species was calculated by 
R. $A=\frac{S . A}{T . A} \times 100$

Where R.A = Relative abundance of each species; S.A = Species abundance, T.A = Total abundance for all species

The relative abundance of each species was also determined qualitatively on a scale of 1-4 indicating whether the species abundance was dominant, sub dominant, occasional or rear

\section{Results}

\subsection{The Ichthyofauna assemblage of Alape River}

The monthly ichthyofauna assemblage, abundance and relative percentage abundance of fish species encountered in Alape River are shown in Tables 1,2 and 3. Table 4, Figures 1 and 2 represent the overall ichthyofauna assemblage, abundance and relative percentage abundance of fish species encountered during the period of study in the river.

\subsection{Species composition of Alape River in Ondo State, Nigeria.}

Six species; Heterotis niloticus, Clarias gariepinus, Chrysichthys nigrodigitatus, Gymnarchus niloticus, Oreochromis aureaus and Hepsetus odoe belonging to six families; Arapaimidae, Clariidae, Claroteidae, Gymnarchidae, Cichlidae and Hepsetidae were recorded.

\subsection{Monthly Ichthyofauna survey}

A total of six thousand six hundred and nineteen $(6,619)$ fishes of the six species, belonging to six families; Arapaimidae, Clariidae, Claroteidae, Gymnarchidae, Cichlidae and Hepsetidae were recorded in the month of November, 2019. As shown in Table 1. The number of individual and relative percentage abundance observed in all the species are as follows; Heterotis niloticus (651 individuals) with a relative percentage abundance of (9.84\%), Clarias gariepinus (1,879 individuals) with a relative percentage abundance of (28.39\%), Chrysichthys nigrodigitatus (1,310 individuals) with a relative percentage abundance of (19.39\%), Gymnarchus niloticus (308 individuals) with a relative percentage abundance of (4.65\%), Oreochromis aureaus (1,617 individuals) with a relative percentage abundance of (24.43\%) and Hepsetus odoe (854 individuals) with a relative percentage abundance of (12.9\%).

Table 1. The fish abundance and percentage (\%) relative abundance in Alape River in November, 2019

\begin{tabular}{|c|c|c|c|c|c|c|c|}
\hline \multirow[t]{2}{*}{ Month } & \multicolumn{7}{|c|}{ Total per Species } \\
\hline & $\begin{array}{l}\text { Heterotis } \\
\text { niloticus }\end{array}$ & $\begin{array}{l}\text { Clarias } \\
\text { gariepinus }\end{array}$ & $\begin{array}{l}\text { Chrysichthys } \\
\text { nigrodigitatus }\end{array}$ & $\begin{array}{l}\text { Gymnarchus } \\
\text { niloticus }\end{array}$ & $\begin{array}{l}\text { Oreochromis } \\
\text { aureaus }\end{array}$ & $\begin{array}{l}\text { Hepsetus } \\
\text { odoe }\end{array}$ & Grand Total \\
\hline \multirow[t]{21}{*}{ November/Daily catch } & 31 & 40 & 52 & 11 & 42 & 32 & \\
\hline & 25 & 55 & 64 & 5 & 51 & 23 & \\
\hline & 35 & 82 & 63 & 6 & 62 & 34 & \\
\hline & 36 & 87 & 73 & 12 & 44 & 40 & \\
\hline & 32 & 67 & 56 & 18 & 73 & 37 & \\
\hline & 33 & 76 & 67 & 19 & 65 & 38 & \\
\hline & 27 & 71 & 42 & 16 & 77 & 27 & \\
\hline & 18 & 73 & 56 & 18 & 61 & 35 & \\
\hline & 26 & 82 & 52 & 13 & 80 & 38 & \\
\hline & 19 & 67 & 47 & 9 & 61 & 32 & \\
\hline & 22 & 62 & 43 & 17 & 75 & 30 & \\
\hline & 37 & 66 & 51 & 6 & 55 & 26 & \\
\hline & 24 & 85 & 64 & 12 & 76 & 45 & \\
\hline & 16 & 77 & 78 & 13 & 43 & 35 & \\
\hline & 27 & 82 & 62 & 7 & 67 & 31 & \\
\hline & 23 & 73 & 72 & 13 & 52 & 28 & \\
\hline & 31 & 72 & 33 & 18 & 74 & 31 & \\
\hline & 22 & 63 & 27 & 6 & 50 & 26 & \\
\hline & 16 & 64 & 43 & 12 & 44 & 31 & \\
\hline & 21 & 57 & 48 & 8 & 60 & 51 & \\
\hline & 23 & 66 & 31 & 4 & 61 & 28 & \\
\hline
\end{tabular}




\begin{tabular}{|c|c|c|c|c|c|c|c|}
\hline \multicolumn{8}{|l|}{ Table 1 continued } \\
\hline \multirow[t]{6}{*}{ Month } & & & & otal pe & & & \\
\hline & 18 & 59 & 28 & 5 & 72 & 33 & \\
\hline & 22 & 81 & 41 & 11 & 81 & 43 & \\
\hline & 30 & 92 & 51 & 15 & 73 & 35 & \\
\hline & 23 & 89 & 29 & 11 & 67 & 22 & \\
\hline & 14 & 91 & 37 & 23 & 51 & 23 & Total \\
\hline Abundance & 651 & 1879 & 1310 & 308 & 1617 & 854 & 6619 \\
\hline \% Relative Abundance & 9.84 & 28.39 & 19.79 & 4.65 & 24.43 & 12.9 & 100 \\
\hline
\end{tabular}

More fish species was caught in the month of December than in the month of November as a total of six thousand, eight hundred and seventy-one $(6,871)$ individuals of the six species, belonging to the six family were recorded Table 2 . Clarias gariepinus had the highest individual number recorded $(1,999)$ as well as the highest relative $\%$ abundance of $(29.09 \%)$ followed by Oreochromis aureaus with 1,871 number of individual and (27.23\%) relative abundance. Chrysichthys nigrodigitatus, Hepsetus odoe and Heterotis niloticus respectively had a number of individual and relative \% abundance of 964 (14.03\%), 899 (13.08\%) and 798 (11.48\%). The lowest sampled species in the month of December was Gymnarchus niloticus with a number of individual and relative \% abundance of 340 (4.95\%).

Table 2. The fish abundance and percentage (\%) relative abundance in Alape River in December, 2019

\begin{tabular}{|c|c|c|c|c|c|c|c|}
\hline \multirow[t]{2}{*}{ Month } & \multicolumn{7}{|c|}{ Total per Species } \\
\hline & $\begin{array}{l}\text { Heterotis } \\
\text { niloticus }\end{array}$ & $\begin{array}{l}\text { Clarias } \\
\text { gariepinus }\end{array}$ & $\begin{array}{l}\text { Chrysichthys } \\
\text { nigrodigitatus }\end{array}$ & $\begin{array}{l}\text { Gymnarchus } \\
\text { niloticus }\end{array}$ & $\begin{array}{l}\text { Oreochromis } \\
\text { aureaus }\end{array}$ & $\begin{array}{l}\text { Hepsetus } \\
\text { odoe }\end{array}$ & Grand Total \\
\hline \multirow{26}{*}{$\begin{array}{l}\text { December/Daily } \\
\text { catch }\end{array}$} & 32 & 73 & 40 & 10 & 77 & 19 & \\
\hline & 17 & 65 & 51 & 8 & 76 & 31 & \\
\hline & 15 & 77 & 44 & 12 & 58 & 32 & \\
\hline & 29 & 81 & 32 & 6 & 82 & 41 & \\
\hline & 20 & 90 & 30 & 17 & 68 & 27 & \\
\hline & 17 & 71 & 31 & 12 & 61 & 19 & \\
\hline & 35 & 81 & 39 & 10 & 77 & 41 & \\
\hline & 37 & 84 & 42 & 11 & 75 & 29 & \\
\hline & 21 & 63 & 44 & 17 & 71 & 31 & \\
\hline & 28 & 81 & 31 & 9 & 84 & 43 & \\
\hline & 31 & 83 & 33 & 15 & 66 & 30 & \\
\hline & 27 & 69 & 21 & 14 & 53 & 37 & \\
\hline & 22 & 81 & 39 & 12 & 61 & 41 & \\
\hline & 21 & 84 & 43 & 13 & 85 & 36 & \\
\hline & 21 & 74 & 39 & 11 & 71 & 41 & \\
\hline & 37 & 91 & 37 & 8 & 94 & 34 & \\
\hline & 36 & 63 & 40 & 15 & 78 & 41 & \\
\hline & 37 & 91 & 51 & 18 & 53 & 29 & \\
\hline & 45 & 77 & 29 & 11 & 79 & 33 & \\
\hline & 54 & 87 & 41 & 21 & 56 & 36 & \\
\hline & 31 & 78 & 51 & 12 & 89 & 46 & \\
\hline & 48 & 102 & 31 & 19 & 81 & 66 & \\
\hline & 37 & 75 & 33 & 15 & 78 & 27 & \\
\hline & 20 & 62 & 23 & 12 & 56 & 29 & \\
\hline & 41 & 55 & 38 & 11 & 77 & 31 & \\
\hline & 39 & 61 & 31 & 21 & 65 & 29 & Total \\
\hline Abundance & 798 & 1999 & 964 & 340 & 1871 & 899 & 6871 \\
\hline $\begin{array}{l}\% \text { Relative Abun- } \\
\text { dance }\end{array}$ & 11.48 & 29.09 & 14.03 & 4.95 & 27.23 & 13.08 & 100 \\
\hline
\end{tabular}

During the course of this study, the highest number of fish was caught in the month of January ( Table 3 ) with a total catch of six thousand nine hundred and nineteen samples $(6,919)$. The number of individual and relative percentage abundance, were observed in all the species as follows; Heterotis niloticus 876 (12.66\%), Clarias gariepinus 1,902 (27.49\%), Chrysichthys 
nigrodigitatus 1,140 (16.47\%), Gymnarchus niloticus 341 (4.93\%), Oreochromis aureaus 1726 (24.95\%) and Hepsetus odoe 934 (13.5\%) respectively.

Table 3. The fish abundance and percentage (\%) relative abundance in Alape River in January, 2020

\begin{tabular}{|c|c|c|c|c|c|c|c|}
\hline \multirow[t]{2}{*}{ Month } & \multicolumn{7}{|c|}{ Total per Species } \\
\hline & $\begin{array}{l}\text { Heterotis } \\
\text { niloticus }\end{array}$ & $\begin{array}{l}\text { Clarias } \\
\text { gariepinus }\end{array}$ & $\begin{array}{l}\text { Chrysichthys } \\
\text { nigrodigitatus }\end{array}$ & $\begin{array}{l}\text { Gymnarchus } \\
\text { niloticus }\end{array}$ & $\begin{array}{l}\text { Oreochromis } \\
\text { aureaus }\end{array}$ & $\begin{array}{l}\text { Hepsetus } \\
\text { odoe }\end{array}$ & $\begin{array}{l}\text { Grand } \\
\text { Total }\end{array}$ \\
\hline \multirow[t]{26}{*}{ January/Daily catch } & 40 & 84 & 44 & 19 & 71 & 21 & \\
\hline & 28 & 93 & 40 & 11 & 84 & 34 & \\
\hline & 22 & 73 & 30 & 9 & 56 & 19 & \\
\hline & 27 & 56 & 41 & 8 & 76 & 14 & \\
\hline & 36 & 81 & 32 & 12 & 71 & 31 & \\
\hline & 31 & 63 & 35 & 13 & 51 & 65 & \\
\hline & 28 & 66 & 42 & 25 & 44 & 32 & \\
\hline & 27 & 78 & 51 & 21 & 68 & 22 & \\
\hline & 41 & 70 & 39 & 10 & 66 & 31 & \\
\hline & 37 & 65 & 45 & 11 & 61 & 28 & \\
\hline & 29 & 88 & 39 & 7 & 81 & 33 & \\
\hline & 36 & 81 & 20 & 9 & 77 & 37 & \\
\hline & 29 & 78 & 41 & 8 & 71 & 44 & \\
\hline & 41 & 77 & 32 & 9 & 61 & 52 & \\
\hline & 27 & 64 & 44 & 15 & 78 & 38 & \\
\hline & 33 & 81 & 41 & 17 & 77 & 41 & \\
\hline & 31 & 57 & 30 & 16 & 71 & 34 & \\
\hline & 28 & 87 & 42 & 23 & 68 & 29 & \\
\hline & 39 & 66 & 51 & 17 & 80 & 46 & \\
\hline & 41 & 71 & 32 & 8 & 74 & 55 & \\
\hline & 39 & 54 & 45 & 11 & 56 & 41 & \\
\hline & 31 & 65 & 66 & 9 & 51 & 32 & \\
\hline & 35 & 79 & 59 & 7 & 61 & 35 & \\
\hline & 36 & 81 & 87 & 23 & 56 & 41 & \\
\hline & 43 & 66 & 45 & 12 & 65 & 39 & \\
\hline & 41 & 78 & 67 & 11 & 51 & 40 & Total \\
\hline Abundance & 876 & 1902 & 1140 & 341 & 1726 & 934 & 6919 \\
\hline \% Relative Abundance & 12.66 & 27.49 & 16.47 & 4.93 & 24.95 & 13.5 & 100 \\
\hline
\end{tabular}

Comparing the monthly abundance of fish species encountered during the period of this study; highest number $(1,879)$ of C. gariepinus was recorded followed by O. aureaus (1617) and C. Chrysichthys (1310) and the least was in G. niloticus (308) in November 2019. In December, 2019 similar pattern of catch was also recorded C. gariepinus recorded highest number (1999) followed by O. aureaus (1871) and C. Chrysichthys ( 964) and the least was in G. niloticus (304). The pattern of encountered fish species was not different from other months of the study in January, 2020.

\subsection{Overall Ichthyofauna survey}

A total of twenty thousand, four hundred and nine $(20,409)$ individuals of the six species, belonging to six families; Arapaimidae, Clariidae, Claroteidae, Gymnarchidae, Cichlidae and Hepsetidae were recorded from the month of November 2019 to January 2020. As shown in Table 4 and Figures 1 and 2, Clarias gariepinus had the highest abundance and relative \% abundance of 5,780 and (28.32\%) throughout the period of study followed by Oreochromis aureaus with 5,214 (25.55\%), Chrysichthys nigrodigitatus had a total abundance of 3,414 with a total percentage abundance of (16.73\%). Hepsetus odoe and Gymnarchus niloticus respectively had a least total number of individual and relative percentage abundance of 2,687 (13.17\%) and 2,325 (11.39\%). The over-all comparison among the months of study shows that highest catch was recorded in January with an overall relative percentage abundance of $33.9 \%$, followed by December with $33.67 \%$. The least catch was observed in the month of November with a relative percentage abundance of $32.43 \%$. 


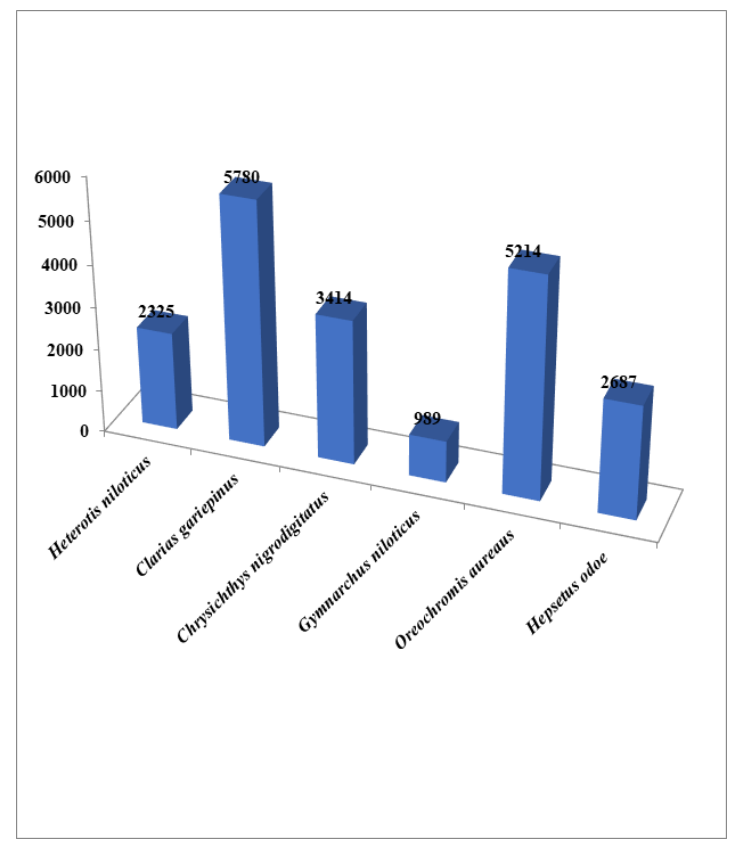

Fig 1. The over-all fish abundance in in AlapeRiver, Ondo State, Nigeria between the months of November 2019 to January 2020

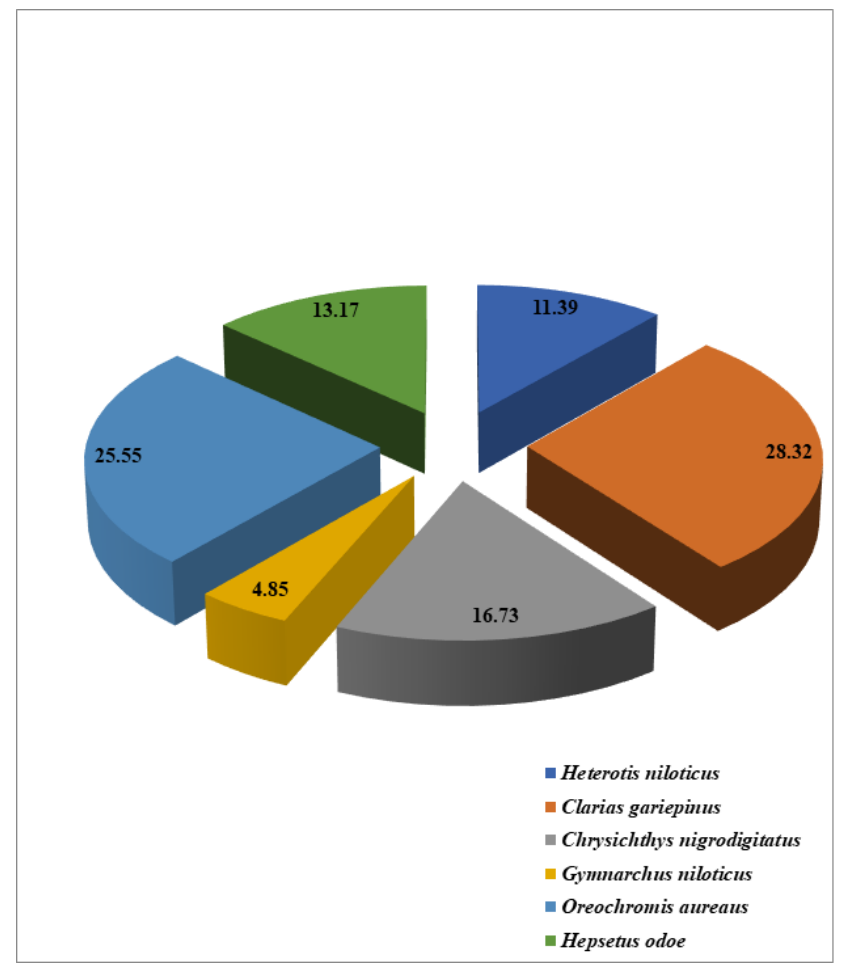

Fig 2. The over-all fish relative percentage (\%) abundance in Alape River in Ondo State, Nigeria between the months of November 2019 to January 2020 
Table 4. Check list of the fish fauna in Alape River showing total monthly abundance and monthly percentage relative abundance from the months of November 2019 to January 2020

\begin{tabular}{|c|c|c|c|c|c|c|c|c|}
\hline \multirow[t]{2}{*}{ Month } & \multicolumn{8}{|c|}{ Total per Species } \\
\hline & $\begin{array}{l}\text { Heterotis } \\
\text { niloticus }\end{array}$ & $\begin{array}{l}\text { Clarias } \\
\text { gariepinus }\end{array}$ & $\begin{array}{l}\text { Chrysichthys } \\
\text { nigrodigi- } \\
\text { tatus }\end{array}$ & $\begin{array}{l}\text { Gymnarchus } \\
\text { niloticus }\end{array}$ & $\begin{array}{l}\text { Oreochromis } \\
\text { aureaus }\end{array}$ & $\begin{array}{l}\text { Hepsetus } \\
\text { odoe }\end{array}$ & Total & $\begin{array}{l}\% \quad \text { Relative } \\
\text { Abundance }\end{array}$ \\
\hline November & 651 & 1879 & 1310 & 308 & 1617 & 854 & 6619 & 32.43 \\
\hline December & 798 & 1999 & 964 & 340 & 1871 & 899 & 6871 & 33.67 \\
\hline January & 876 & 1902 & 1140 & 341 & 1726 & 934 & 6919 & 33.9 \\
\hline Abundance & 2325 & 5780 & 3414 & 989 & 5214 & 2687 & 20409 & \\
\hline \% R.A & 11.39 & 28.32 & 16.73 & 4.85 & 25.55 & 13.17 & & 100 \\
\hline Dominancy & Occasional & Dominant & $\begin{array}{l}\text { Sub- } \\
\text { dominant }\end{array}$ & Rare & Dominant & Occasiona & & \\
\hline
\end{tabular}

\section{Discussion}

From the study a total of twenty thousand, four hundred and nine $(20,409)$ individual of the six species, belonging to six families; Arapaimidae, Clariidae, Claroteidae, Gymnarchidae, Cichlidae and Hepsetidae were caught between the months of November 2019 to January 2020. These were identified and classified into 6 species of fish representing 6 families. This species abundance was higher than the results of other studies in other water bodies. Bassy ${ }^{(15)}$ recorded a total of Seventeen thousand, four hundred and sixty-four $(17,464)$ fish samples collected from Calabar River, Nigeria. Olawusi-Peters et al. ${ }^{(8)}$ also observed lower catch $(6,701)$ in Agboyi Creek, Lagos State during the dry season

Bolarinwa $^{(16)}$ recorded 8942 in the coastal waters of Ondo State during the dry season. However, the result of this study is lower in terms of numbers of species and family composition when compared with the findings of Bolarinwa and Okeowo ${ }^{(16)}$ who recorded a total fish sample collection of two thousand five hundred and fifty (2550) belonging to 64 species from 39 families in Badagry coastal waters of Lagos State, Nigeria. Eight of the 64 species which were predominant include Pseudotolithus senegalensis, Trachinotus goreensis, Tilapia zilli, Chrysichthys nigrodigitatus, Polydactylus quadrifilis, Ethmalosa fimbriata, Pomadasy jubelini and Sphyraena piscatorum. Onuoha et al. ${ }^{(17)}$ recorded a total of 552 piscine specimens which belonged to 4 orders, 7 families, 14 genera and 26 species. Adewumi et al. ${ }^{(7)}$ also recorded a total number of 2,700 individual of 9 species, belonging to six families; Clariidae, Mormyridae, Cichlidae, Hepsetidae, Malapteruridae and Channidae in Ogbese River Ekiti, State. There is similarity in the number of families recorded by Adewumi ${ }^{(7)}$ to the present findings but differs in recording 9 species instead of 6 species from this work.

During the course of this study, six species, belonging to six families; Arapaimidae, Clariidae, Claroteidae, Gymnarchidae, Cichlidae and Hepsetidae were recorded. The six species representing these families includes; Heterotis niloticus, Clarias garie pinus, Chrysichthys nigrodigitatus, Gymnarchus niloticus, Oreochromis aureaus and Hepsetus odoe. These fish families and species have been observed by many fisheries workers and researchers and found to constitute the major fisheries of inland waters in Nigeria due to their ability to adapt to various water conditions ${ }^{(7)}(16,17)$.

The fish family with the highest abundance was family Clariidae. This is in agreement with the reports of Onuoha et al. ${ }^{(17)}$ and Bolarinwa and Okeowo ${ }^{(16)}$ but in disagreement with the findings of Adewumi et al. ${ }^{(7)}$. Clarias spp. are largely believed to be the most important fish species in West Africa in regards to their nutritional, economic and biological importance. The family Clariidae is represented by Clarias gariepinus in this study. This species is of major economic importance and also an important aquaculture species thus it was introduced all over for farming purposes in the early 1980s.

The abundance of families of Clariidae followed by Chiclidae represented by C. gariepinus followed by O. aureaus. In this study could be as a result of their ability to utilize a wide range of food items in the lower trophic level as herbivores, their hardiness, and ability to withstand low dissolved oxygen level as well as their high fecundity and prolific nature. The families Arapaimidae, Claroteidae, Gymnarchidae and Hepsetidae also had a high representation in the catch. This could also be due to their hardy nature and higher susceptibility to catch.

Fish community study is not generally equivalent to Ichthyocoenoses because the description of any fish community is a biased image arising from the sampling of a group of fishes in a particular environment at a given time. The use of gear and sampling strategies are the usual source of these biases ${ }^{(7)}$ The relatively low species composition in this study compared with other similar studies with high species richness such as Bolarinwa and Okeowo ${ }^{(16)}$ in Badagry coastal water, Nigeria, could be 
due to the use of multiple gears in those sites. Allison et. al., ${ }^{(18)}$ suggested a multiple gear approach as the best way to obtain comprehensive icthyofauna samples for such studies.

The discrepancy could also be due to the short period of survey that excludes extensive seasonal variation in catch, Adewumi et.al., ${ }^{(7)}$ made similar observation in Ogbese River. Only six species and six families were encountered during the period of study. This does not mean that there are no other species and families in Alape River. Ufodike et. al., ${ }^{(19)}$ reported that hooks and net are essential in maximizing fish catch. They may not be encountered due to the type of gear used and the short period of the study, which has not taken care of seasonal variations.

\section{Conclusion}

The wide coverage of Alape River makes it to be of particular interest and with proper management, it could be developed for multi-usage purposes such as transportation, electricity generation etc. Challenges encountered in this study were lack of basic communication with the fishermen as most of them could only understand their local dialect. Also, most fishermen could only identify all the fish species in their local dialect. It is hoped that the information gathered from this study will be very useful in formulating management policies that would be useful in future management of Alape River. Considering its fairly low fish families and species composition, there is need for further survey to cover many months. There is also a need to evolve strategy for effective utilization and proper management of the river. If properly managed, the River will go a long way in boosting the economic status of the State and also the Nation.

\section{References}

1) Obany OD, Asaad HM, Agib MA, El-Faki FE, Ali ME. Comparative studies on nutritive value of wild and farmed African catfish Clarias gariepinus. International Journal of Fisheries and Aquatic Studies. 2016;4(3):327-329.

2) FDF. Fisheries Statistics of Nigeria. In: and others, editor. Federal Department of Fisheries. 2015.

3) (WRI) WRI. Earth Trends: Environmental information. 2003. Available from: http://www.wri.org/our-work/project/ earthtrendsenvironmentalinformation2003.

4) Segun OO, Moshood KM, Lateefat KS, Abass TA. Fish composition and diversity assessment of Apodu Reservoir, Malete, Nigeria. International Journal of Fisheries and Aquatic Studies. 2018;6(2):89-93.

5) Abiodun JA, John P. Biodiversity and abundance of fish and some processing methods in Lower Niger River. Nigeria Journal of Fishery and Aquaculture. 2017;5(2):20-25.

6) Ayamre, Ekelemu JK. Abundance and distribution of fish species in three water bodies in Asaba Metropolis. Journal of Agriculture and Environmental Sciences. 2016;p. 149-154.

7) A AA. A Survey of the Ichtyofauna of Ogbese River, South West, Nigeria. International Journal of Sciences. 2015;7(4):1-5. doi:10.18483/ijsci.726.

8) Olawusi-Peters, Oo A, Ao. Species abundance and distribution patterns of some shellfishes in coastal waters of Ondo State. International Journal of Fauna and Biological Studies. 2014;1(4):19-24.

9) Josef BB, Fasakin EA, Fagbenro AO. The species composition and diversity of the coastal waters of Ondo State. Nigeria American Research Journal of Agriculture . 2012;3.

10) FAO. The State of World Fisheries and Aquaculture. Rome, Italy. 1999.

11) UNDP. Human Development Report, the real wealth of nations: path ways to Human Development. Palgrave. 2010.

12) Ogunbadejo HK, Alhaji T, Otubusin S. Productivity of labor in Artisanal fish farming in Nigeria. African Journal of Applied Zoology and Environmental Biololgy. 2007;9:74-77.

13) Babatunde OO, Raji A. Field Guide to Nigeria Freshwater Fishes. 1998.

14) Idodo-Umeh G. Freshwater fishes of Nigeria (Taxonomy, ecological notes, diets and utilization). Idodo-Umeh Publisher. 2003;p. 11-211.

15) Bassy JK. Fish distribution in Calabar River. Nigerian Journal of Fish Biology. 2016;29:489-498.

16) Bolarinwa JB, Okeowo TO. The species composition and diversity of the coastal waters of Badagry. Global Journal of Agricultural Research. 2017;p. 26-31.

17) Onuoha GC, Ekpo IE, Chude LA, Isangedighi IA. Composite preliminary Ichthyofaunal survey of Ntak Inyang Stream, Ikpa River, Nigeria. Nigerian Journal of Agriculture, Food and Environment. 2010;6(1\&2):82-89.

18) Allison ME, Gabriel UU, Inko-Tariah MB, Davies OA, Udeme-Naa B. The fish Assemblage of Elechi Creek, River State, Niger Delta. Biologica. 1997;2(1):9096.

19) Ufodike JT, Poston YR, Francis YR, Ikomi RB. Ichthyology: The study of fishes. John Wiley and Sons Inc. New York and London. $2001 ;$ p. 545. 